\title{
THE EFFECT OF ALOE VERA EXTRACT AND DISCHARGE PLANNING TO ACCELERATE WOUND HEALING OF OLDER ADULT HERNIA SURGERY PATIENTS
}

\author{
Mukhammad Toha ${ }^{1 *}$, Mokh Sujarwadi ${ }^{1}$, Ida Zuhroidah ${ }^{1}$ \\ ${ }^{1}$ Jember University, Pasuruan Campus \\ *Correspondence: \\ Mukhammad Toha \\ Email: toha.akper@unej.ac.id \\ Address: Jember University, Pasuruan Campus, Jl. KH. Mansyur No.207, Tembokrejo, Kec. Purworejo, \\ Pasuruan City, East Java Province 67118
}

\begin{abstract}
Background: Older adult patients who underwent hernia surgery commonly get obstacles in the process of wound healing as a result of decline of body functions. Aloe vera which contains of anti-inflammatory, anti-microbial and skin fibroblasts stimulator, can be used as adjunctive therapy in treating wounds.

Objective: This study aimed to identify the effect of aloe vera extract and discharge planning to accelerate wound healing of older adult hernia surgery patients at dr. R. Soedarsono General Hospital, Pasuruan.

Method: This study uses Quasi-Experimental with Static-group comparison approach. The population is all post-operative hernia patients aged 55-65 years at the operating room of dr. R. Soedarsono General Hospital, Pasuruan. The sample consists of 20 respondents taken according to the inclusion criteria. The independent variable is the treatment of wounds using aloe vera extract accompanied by discharge planning, while the dependent variable was the acceleration of wound healing especially inflammatory and proliferation phases. The data were collected through observation of macroscopic current wound care. Data were analyzed using nonparametric Mann Whitney test with significance level of $\leq 0.05$.

Result: The results showed the effect of the treatment using aloe vera extract and discharge planning to accelerate wound healing of older adult hernia surgery patients, the inflammatory phase of healing occurs on the sixth day for inflammation, exudation, and edema $(p=$ $0.022, p=0.028$, and $p=0.029$, respectively). The proliferative phase occurs on day three with $p=0.015$.

Conclusion: This research indicates further research on the benefits of aloe vera and discharge planning for wound healing especially in older adult patients is required. Thus, a stronger basis for recommending aloe vera extract as complementary therapy for wound care is available.
\end{abstract}

Key words: Aloe Vera, Discharge Planning, Surgical Wound, Older Adults Age.

\section{INTRODUCTION}

Wound is an injury experienced by humans. Wound is defined as losing epithelial integrity from skin (Schwartz et al, 2010). Smeltzer dan Bare (2010) state that wound can be distinguished by contamination consisting of clean wound, contamined clean wound, and dirty wound. Clean wound generally comes from surgery process, which has passed incission procedure prepared aseptically. Its healing takes fast because there is no infection.

At Dr. R. Soedarsono General Hospital, Pasuruan, wound care procedures performed using a solution of $\mathrm{NaCl} 0.9 \%$. However, older adults who had hernia surgery takes days foor wound healing. At the tenth day after surgery, the wound is 
still moist. The wound edges are not fully connected. It is painful and inflammated. Those condition are not suitable with a theory stated that at the 7-10 day, the surgical suture can be released and the wound has been in good condition. (Mansjoer, 2014).

The unhealed wound will trigger some risks, such as bleeding, infection, dehisens, and eviserations (Mansjoer, 2014). The problem in wound treatment after hernia surgery of older adults can be special attention in nursing. In caring patients, nursing profession is demanded to develop the independent and safe nursing intervention. Exploring natural stuffs containing chemical substance as antiseptic and micronutrient is developed since it is able to help wound healing process. It is included to complementary nursing. This effort is proper to Regulations of Nursing Practical Implementation stating that nursing practice is aimed for individu, family, group, and society through promotive preventive activities, social empowerment, and complementary nursing actions (Depkes RI, 2010).

Aloe vera (Aloe vera linn) contains many subtances which are useful to precipitate wound healing by (1) serving essential micro-nutrient; (2) antiinflammatory effect; (3) anti-microba effect; and (4) stimulating skin fibroblasts. Aloe vera also gives positive effects for collagen balance which has importatnt role in wound healing. Nevertheless, the effects of aloe vera for hernia wound healing process of older adults.

Wound healing process in hernia surgey of older adults needs more intensive care. It is not only at the hospital, but also at home. Thus, health promotion needs to be prepared, both for clients and family who will take care of the patient. Discharge planning is a process of preparing patients before they go back to home. The process identifies the needs and plans for facilitating the continuity of treatment either at home or another health servie unit
(Kozier, 2008). Discharge planning for patients after surgery is not implemented well in dr. R. Soedarsono General Hospital. The informations given are only controlling time and instruction of taking medicine. Most discharge planning is used in resume of patients.

Data from Operating Rooms of dr. R. Soedarsono General Hospital reveal that in 2014 hernia was in the first position (209 cases). In 2015, that case increased to 330 cases, while in 2016 it decreased into 255 cases. For case distribution based on age, there were $138(54 \%)$ patients at the age of 55 years and more. 117 patients (46\%) were at the age of less than 55 years old. The data proved that most of its patients were older adults. Based on the medical records from Surgery Unit of dr.R. Soedarsono General Hospital in 2015, the surgical suture in less 55 years old patients were released at the tenth day. Meanwhile, for older patients, the surgical sutures were put off at the fifteenth day. The releasing process of surgical suture is executed when the wound has been dry and its edges united, so that surgical suture is not necessary.

Wound healing process is divided into three main phase, these are: 1) hemostasis and inflammation, 2) proliferation, 3) maturity and remodelling. These phases are overlapping and they happen since the wound comes out until healing process. (Wilksman et al, 2007). Inflammation phase is the first phase of wound healing process. At this condition, the wound is reddish and inflammed. The body increases its temperature and the pain comes. This step takes 3-4 days after injury. This healing process means cleaning process of the rests. Inflammation response causes the artery seeps and releases plasma and PMN (polymorphonuclecytes) around the tissue. Neutropils along with local cells phagocyte the rests and microorganisms.

Proliferation phase starts at the fourth day after injury and takes until the $24^{\text {th }}$ day. Clinically, this phase is marked by red tissue which replace dermal tissue. After 
that, fibroblasts secrete the collagen for regenerating cells along with angiogenesis and epithelization. In the last process of epithelization, contracture happens where keratinocytes differentiate to form outside protective layer or stratum korneum. After the basic structures completed, finishing interior starts. Dermal tissue increases its power by fibroblasts. Maturation phase or remodelling takes one year or more after injury (Aminuddin, 2009).

There are many technics for treating wounds, one of them is applying antiseptic substances which are often used for treating wounds. These antiseptic stuffs have antimicrobial substances which can fight microorganism in wounds. However, it also has its side effect, these are irritated skin, skin color change, and scar tissue because scar tissue is due to foreign object during the wound healing process (Kurniawan, 2007). Because of the side effects from chemical substances, the wound treatment uses normal saline solvent. This solvent is easy to absorb by the body, thus it will not create disadvantages.

Aloe vera is plantable and easy to find everywhere. In some countries, people use aloe vera as the first aid of treating wound. Aloe vera contains active substances which are useful for precipitating in healing wound. It contains glucomanan, acemannan saponin, lignin, vitamin $\mathrm{A}$, vitamin $\mathrm{C}$, enzyms and amino acid for regenerating cells. Aloe vera stimulates epidermic, increase fibroblasts function, and form the new blood vessels (Furnawanthi, 2006).

This study aimed to identify the effect of aloe vera extract and discharge planning to accelerate wound healing of older adult hernia surgery patients at dr. R. Soedarsono General Hospital, Pasuruan.

\section{METHODS}

\section{Study Design}

This research uses Quasi Experimental design, with static-group comparison design approach.

\section{Setting}

This research was conducted at the dr. R. Soedarsono General Hospital, Pasuruan on February to March 2017.

\section{Research Subject}

The population for objects is entire patients of hernia surgery at the age of 5565 years old in surgery room of dr. R. Soedarsono General Hospital, Pasuruan. The samples consist of 20 respondents with inclusion criteria, namely male gender, had albumin levels of 3.5-4.5 g\%, Hb levels of 10-14 g\%, GDA 85-125 mg\%, using consecutive sampling method. The independent variable in the treatment group here is wound treating process using topical aloe vera extract after cleansing with $\mathrm{Na} \mathrm{Cl}$ $0.9 \%$ along with discharge planning, while in the control group the surgical wound treating without topical aloe vera extract was given. Moreover, the dependent variable is precipitation of wound healing after hernia surgery in inflammation and proliferation phases.

\section{Instruments}

The instruments used are observation reports about wound healing after hernia surgery. These are inflammatory phase including inflammation, edema, and exudation. Meanwhile, proliferation phase includes measuring uniting wound edges. The measurement of wound healing is done macroscopically in the third and sixth day after surgery without pretest.

\section{Data Analysis}

The collected data are analyzed using Mann Whitney test with $\leq 0.05$ for meaning level compared to controlling and measuring group in each measuring session.

\section{Ethical Consideration}

This research has gone obtained permission from the director of the dr. R. Soedarsono General Hospital, Pasuruan 
with number license of Permit Letter: 800/734/423.212/2017.

\section{RESULTS}

Examination of the Effect of Aloe Vera Extract and Discharge Planning to Accelerate Wound Healing of Older Adult Hernia Surgery Patients at $d r . \quad R$.

Table 1. Examination of the Effect of Aloe Vera Extract and Discharge Planning to Accelerate Wound Healing (Inflammatory Phase) of Older Adult Hernia Surgery Patients on Sixth Days After Surgery at dr. R. Soedarsono General Hospital, Pasuruan by using Mann Whitney Test $(\mathrm{n}=20)$. Soedarsono General Hospital, Pasuruan

Table 2. Examination of the Effect of Aloe Vera Extract and Discharge Planning to Accelerate Wound Healing (Proliferation Phase) of Older Adult Hernia Surgery Patients on Third Days After Surgery at dr. R. Soedarsono General Hospital, Pasuruan by using Mann Whitney Test $(\mathrm{n}=20)$.

\begin{tabular}{lccccc}
\hline Component of & \multicolumn{4}{c}{ Group } & \multirow{2}{*}{$\begin{array}{c}\text { Asymp. } \\
\text { Proliferation }\end{array} \quad$} \\
\cline { 2 - 5 } \multicolumn{1}{c}{ Phase } & Control & Treatment & Sig. \\
\cline { 2 - 5 } & $\mathbf{N}$ & $\%$ & $\mathbf{N}$ & $\mathbf{\%}$ & \\
\hline Uniting & & & & & 0.015 \\
Wound & & & & & \\
Healing & & & & & \\
$\quad$ Not Uniting & 4 & 40 & 0 & 0 & \\
Some & 6 & 60 & 8 & 80 & \\
Entire & 0 & 0 & 2 & 20 & \\
Total & 10 & 100 & 10 & 100 & \\
\hline$\quad$ Source: Primary data of questionnaire, 2017 &
\end{tabular}

\begin{tabular}{lccccc}
\hline \multirow{2}{*}{$\begin{array}{l}\text { Component of } \\
\text { Inflammatory }\end{array}$} & \multicolumn{4}{c}{ Group } & \multirow{2}{*}{ Asymp. } \\
\cline { 2 - 5 } & \multicolumn{2}{c}{ Control } & \multicolumn{2}{c}{ Treatment } & Sig. \\
\cline { 2 - 5 } & $\mathbf{N}$ & $\mathbf{\%}$ & $\mathbf{N}$ & $\mathbf{\%}$ & \\
\hline Inflammation & & & & & 0.022 \\
$>2 \mathrm{~cm}$ & 0 & 0 & 0 & 0 & \\
$0.6-2 \mathrm{~cm}$ & 6 & 60 & 1 & 10 & \\
$\quad$ No & 4 & 40 & 9 & 90 & \\
Total & 10 & 100 & 10 & 100 & \\
\hline Edema & & & & & 0.029
\end{tabular}

\begin{tabular}{lccccc} 
Edema & & & & & 0.029 \\
$>2 \mathrm{~cm}$ & 0 & 0 & 0 & 0 & \\
$0.6-2 \mathrm{~cm}$ & 4 & 40 & 0 & 0 & \\
No & 6 & 60 & 10 & 100 & \\
Total & 10 & 100 & 10 & 100 & \\
\hline
\end{tabular}

\begin{tabular}{lccccc}
\hline Exudation & & & & & 0.028 \\
Unclear & 0 & 0 & 0 & 0 & \\
Clear & 8 & 80 & 3 & 30 & \\
No & 2 & 20 & 7 & 70 & \\
Total & 10 & 100 & 10 & 100 & \\
\hline \multicolumn{2}{l}{ Source: Primary data of questionnaire, 2017}
\end{tabular}

Based on table 1, It was found that the use of Aloe Vera Extract significantly had an impact on the inflammatory process, both inflammation, edema, and exudation $(p=0.022, p=0.029, p=0.028$, respectively).
The results on the table 2 found that the use of Aloe Vera Extract on day $3^{\text {rd }}$ had a significant impact on the proliferation phase (uniting wound healing) $(p=0.015)$.

\section{DISCUSSION}

The results of this study found that the use of Aloe Vera Extract significantly had an impact on the inflammatory process, both inflammation, edema, and exudation $(p=0.022, p=0.029, p=0.028$, respectively). Inflammation is a response toward lesion in living tissue which has vascularization (Kumar, 2008). Vascular and cellular response happen when the tissue is cut or injured. Vasoconstriction of blood vessel happens and clotted fibro platelet is formed to control the bleeding. This reaction takes five until ten minutes and is followed by vasodilation of venular. Microcirculation loses its vasoconstriction ability because norepinephrine is ruined by intracellular enzyme. Histamine is released to increase permeability of capillary (Smeltzer dan Bare, 2010).

When microcirculation breaks, blood elements such as antibody, protein plasma, electrolyte, complement, and water come into vascular spatial in two until three days. It creates edema, increased temperature, 
redness, and pain. The first thing happening is inflammation. When inflammatory reaction appears, arteriolar enlarges. Hence, much more blood flows into local microcirculation. The stretched capillary is filled by the blood. This condition is hyperemia or congestion triggering redness in severe inflammation. The change of local $\mathrm{pH}$ or local concentration of certain ions can stimulate tip of nerves. The release histamine or other bioactive substances can stimulate nerves. Some of inflammation is caused by hyperemia, and most of it is triggered by liquid supply and cells from blood circulation into interstitial tissue.

Exudation is the extra vascular inflammatory liquid, with high density (more than 1.020). It contains $2-4 \mathrm{mg} \%$ protein with emigrating leukocyte. This liquid is heaped up as the impact of vascular permeability increase, more intravascular hydrostatics as the impact of increased local blood circulation, and any other complicated things causing emigrating leukocyte (Kumar, 2008).

The inflammation healing phase using aloe vera extract and discharge planning on the third day does not result well compared to controlling method. It is related to the age factor, that is elderly will take more time for healing process. In elderly, Langerhans cells reduce and macrophage becomes less active, hence they reduce immune activity within the skin. Moreover, the less perspiration process makes the skin dry, so the healing process takes more time. It is proved when in the third day, the wound is still $60 \%$ reddish and has $30 \%$ edema. Besides, $70 \%$ patients still have moist wound. According to Gaylene and Patricia (2000), one of the factors obscuring wound healing is about age.

Extension of inflammation phase, basically occurs in two groups. Nevertheless, the group which uses aloe vera and discharge planning for treating wound takes shorter period in healing the wound. Probably it is due to saponin content in aloe vera. Saponin is able to be antiseptic and cleanser to fight against germs and bacteria. According to Cowsert (2010) and Kathuria (2011), ace Annan has anti-inflammatory effect by reducing bradykinin and histamine activities. Meanwhile, enzymes bradykinesia and peptidase are able to construct bradykinins as anti-inflammation without toxicity effect. Furthermore, using $\mathrm{Na} \mathrm{Cl} 0.9 \%$ as cleansing in wound treatment keeps the wound moist. The moist condition only keeps the situation optimal for granulation growth, hence redness, inflammation, and exudation continue.

Discharge planning is a method to help patient reaching optimal health level by promoting health to patient and family One of the promotion methods is informing of how important early mobilization and its steps. The comparison of patient independence level for treatment group and controlling group shows that there is no significant difference $(\mathrm{p}=0.137)$. However, descriptically it shows that independence level of treatment group is higher. The early mobilization for patients after surgery can help the blood circulation runs well. Therefore, inflammatory phase can be minimized.

The effect of aloe vera in inflammation healing process is supported by a research by Akhoondinasab et.al (2014). They said that applying $300 \mathrm{mg} / \mathrm{kg}$ mannose-6phosphate for mouse is able to accelerate wound healing process compared to giving sodium chloride $0.9 \%$ by controlling group. On the other hand, Hunter et.al (2006) stated that chromones 8-C-glucosyl-(2'-Ocinnamoyl)- 7-O-methylaloediol $A$ given 200 micrograms to mouse can help equally with giving 200 micrograms hydrocortisone and does not reduce thymus gland size. Anti-inflammation is also resulted from brady kinase, carboxypeptidase enzyme and salicylic acid contained in aloe vera.

The research result for proliferation phase shows differences between wound treatment using aloe vera along with 
discharge planning, and controlling group. Level of wound edges uniting on the third, day after surgery shows significance value $p<0.05(p=0.015)$. It is the proof that treating wound using aloe vera along with discharge planning significantly affects toward wound edges uniting since the third day.

Proliferation phase is the continuing of inflammation phase. If inflammation phase is successful, it will be followed by proliferation phase. Fibroblasts multiply themselves and form the tissues for migrating cells. Epithelia cells form bud on the wound edges. The bud will bloom into capillary which is nutrition source for the new granule tissue. In this phase, fiber is formed and destroyed to adapt with wound stretching. (Sjamsuhidajat dan Jong, 2011).

Surgical wound treatment using $\mathrm{NaCl}$ $0.9 \%$ is aimed to keep skin's humidity that the wound will be healed soon. However, for elderly, they have low ability of absorption, thus the mass of liquid reduces $2.5 \%$ especially in dermal layer. Fibroblasts producing collagen and elastin decrease. The less Langerhans cells and less active macrophage reduce dermal immune activity. The dermal blood vessel becomes thicker and less permeable. The adipose fat tissue loses, so the migrating process of cells to surface takes longer period.

Aloe vera contains lignin which can increase skin absorbing ability. The research from Dal'Belo et.al (2006) about effect of aloe vera for skin hydration showed that aloe vera is a natural stuff which can hydrate skin effectively. According to Laursen and Nielson (2000) in Ramamorty (2011), in wound healing process, glucomannan completes by lectin way where mannose sugar component stimulates secretion of mannose binding lectin protein (MBL). It is tied with carbohydrate of bacteria wall. This bond acitifies $3 b$ complement functioned as chemotaxis and opsonization, hence macrophage becomes more active in eradicating the germs. Macrophage will release Epidermal Growth Factor (EGF), Transforming Growth Factor $\beta 1$ (TGF), Fibroblast Growth Factor (FGF) dan Interleukins (IL-1) besides other cytokines. (Perdanakusuma, 2007). Ramamorty (2011) and Cowsert (2010) stated that Acemannan actifies macrophage and increase nitric oxide synthase in transcription level followed by increasing of $T G F-\beta, E G F, F G F$. They stimulate proliferation, cellular motion, contractility, differentiation, and angiogenesis which are crucial in wound healing process. The hypothesis is supported by a research from Atiba, et al (2011) stating that aloe vera can increase wound healing process. Aloe vera works through junctional intercellular stimulating communication and proliferation fibroblasts. Minerals and vitamins, especially vitamin $\mathrm{C}$ in aloe vera help fibroblast in forcing collagen.

Type I and III collagen are the primary dermal component which are important in proliferation. In wound healing process after hernia surgery, granulation tissue is not visible and scar tissue forming is minimal. It happens because the wound is tight, sterile, and minimum for tissue disorder. This wound healing process runs well and fast. Basically, the wound healing process in inflammation and proliferation phase occur in two groups. However, the treatment using aloe vera extract along with discharge planning runs more fast compared to the group using $\mathrm{Na} \mathrm{Cl} 0.9 \%$. Consequently, the wound healing process happens primarily. The result of this research proves that aloe vera along with discharge planning work well in wound healing process after hernia surgery in older adults.

\section{CONCLUSION}

The wound healing process after hernia surgery in older adults takes shorter period by using aloe vera extract along with discharge planning. It takes more fast compared to controlling group. Healing process of inflammation happens seriously 
on the sixth day, while proliferation phase occurs on the third day.

\section{SUGGESTIONS}

Applying 25\% aloe vera extract on the wound after hernia surgery is recommended because it significantly speeds up the wound healing process, both in inflammation and proliferation phase. Discharge planning can affect significantly toward level of depression after surgery, so that it can speed up wound healing process. The next researcher should modify nursing service in which respondent can stay and get treatment every day. Aloe vera extract is applied daily hence the phytochemical effect will be more optimal. The next researcher should study the effect of aloe vera for pain, inconvenience, psychological acceptance and financial matters.

\section{ACKNOWLEDGMENT}

The authors would like to thanks to Director of Pasuruan Nursing Academy as permit of this research, and to dr. R. Soedarsono General Hospital, Pasuruan as a research site.

\section{DECLARATION OF CONFLICTING INTEREST}

None.

\section{FUNDING}

The funds used in this study came from the researchers' personal funds.

\section{AUTHOR CONTRIBUTION}

Mukhammad Toha: Conduct research as the research leader and compile manuscripts.

Mokh Sujarwadi: Conduct research.

Ida Zuhroidah: Conduct research.

\section{ORCID}

Mukhammad Toha

https://orcid.org/0000-0002-2648-0626

Mokh Sujarwadi

https://orcid.org/0000-0002-3818-0671

Ida Zuhroidah

https://orcid.org/0000-0002-4544-0099

\section{REFERENCES}

Afandi, M.F. (2011). Kemampuan Penyembuhan Luka dengan Lidah Buaya. Retrieved from http://kesehatan.kompasiana.com/alter natif/2011/01/01/kemampuanpenyembuhan-luka-pada-aloevera.

Akhoondinasab, M.R., Akhoondinasab, M., Saberi, M. (2014). Comparison of healing effect of aloe vera extract and silver sulfadiazine in burn injuries in experimental rat model. World journal of plastic surgery, 3(1), 29.

Aminuddin. (2009). Prinsip Dasar Penyembuuhan Luka. Retrieved from http://aminetn.

Wordpress.com/2009/07/26/prinsip dasar-penyembuhan-luka/

Atiba, A., Nishimura, M., Kakinuma, S., Hiraoka, T., Goryo, M., Shimada, Y., Uzuka, Y. (2011). Aloe vera oral administration accelerates acute radiation-delayed wound healing by stimulating transforming growth factor- $\beta$ and fibroblast growth factor production. The American Journal of Surgery, 201(6), 809-18.

Atik, N. dan Iwan J. (2009). Perbedaan Efek Pemberian Topikal Gel Lidah Buaya (Aloe vera L.) dengan Solusio Povidone Iodine terhadap Penyembuhan Luka Sayat pada Kulit Mencit (Mus musculus). MKB. 2009:8:2:87-93.

Banu, A., Sathyanarayana, B., \& Chattannavar, G. (2012). Efficacy of fresh Aloe vera gel against multi-drug resistant bacteria in infected leg ulcers. 
The Australasian medical journal, 5(6), 305.

Chithra, P., Sajithlal, G.B., \& Chandrakasan, G. (2008). Influence of Aloe Vera on Collagen Characteristics in healing Dermal Wounds in Rats. Mol-Cell-Biochem, 181(1-2), 71-76.

Cowsert, Lex, M. (2010). Biological Actifities of Acemannan. Retrieved from

http://www.symmetrydirect.com/pdf/ Bioactivofacemannan.pdf.

Choonhakarn, C., Busaracome, P., Sripanidkulchai, B., Sarakam, P. (2010). A Prospective, randomized clinical trial comparing topical aloe vera with $0.1 \%$ triamcinolone acetonide in mild to moderate plaque psoriasis. Journal Eur Acad Dermatol Venereol, 24(2), 168-72

Dal'Belo, S.E., Gaspar, L.R., Maia, Campos, P.M. (2006). Moisturizing effect of cosmetic formulations containing Aloe vera extract in different concentrations assessed by skin bioengineering techniques. Skin Research Technol, 12(4), 2441-6.

Das, S., Mishra, B., Gill, K., Ashraf, M.S., Singh, A.K., Sinha, M., Singh, T.P. (2011). Isolation and characterization of novel protein with anti-fungal and anti-inflammatory properties from Aloe vera leaf gel. International Journal of Biological Macromolecules, 48(1), 38-43.

Departemen Kesehatan RI. (2010). Izin dan Penyelenggaraan Praktik Perawat, Permenkes republic Indonesia No HK.02.02/Menkes/148/2010. Pasal 8.

Egesie, U., Chima, K., \& Galam, N. (2011). Anti-inflammatory and analgesic effects of aqueous extract of Aloe Vera (Aloe barbadensis) in rats. African Journal of Biomedical Research, 14(3), 209-12.

Eshghi, F., Hosseinimehr, S.J., Rahmani, N., Khademloo, M., Norozi, M.S., \& Hojati, O. (2010). Effects of Aloe vera cream on posthemorrhoidectomy pain and wound healing: results of a randomized, blind, placebo-control study. The Journal of Alternative and Complementary Medicine, 16(6), 64750.

Furnawanthi, I. (2006). Khasiat \& Manfaat Lidah Buaya Si Tanaman Ajaib. Purworejo: Agro Media Pustaka.

Hosseinimehr, S.J., Khorasani, G., Azadbakht, M., Zamani, P., Ghasemi, M., \& Ahmadi, A. (2010). Effect of aloe cream versus silver sulfadiazine for healing burn wounds in rats. Acta Dermatovenerologica Croatica, 18(1), 0-0.

Hutter, J.A., Salman, M., Stavinota, W.B., Satsangi, N., Williams, R.F., Streeper, R.T., \& Weintraub, S.T. (2006). Antiinflammatory C-glucosyl Chromone from Aloe Barbadensis. $J$ Nat-Pro, 59(5), 541-543.

Irshad, S., Butt, M., \& Younus, H. (2011). In-vitro antibacterial activity of Aloe barbadensis Miller (Aloe vera). International research journal of pharmaceuticals, 1(2), 59-64.

Ismail. (2007). Luka dan Perawatannya. Retrieved from http://images. Mailmkes.multiply.multiplaycontent.c om/attachment/0/RDd@AoKCEMAA Dk5LMI1/Merawat $\% 201$ luka.pdf?nmid $=88915450 \quad$ on November $20^{\text {th }}, 2011$.

Junquiera, L.C., Carneiro J. (2007). Basic Histology: Text and Atlas. (Edisi ke11). New York: McGraw-Hill.

Khorasani, G., Hosseinimehr, S.J., Azadbakht, M., Zamani, A., \& Mahdavi, M.R. (2009). Aloe versus silver sulfadiazine creams for seconddegree burns: a randomized controlled study. Surgery today, 39(7), 587-91.

Kumar, V., Abbas, A.K., Fausto, N., Aster, J.C., Robbins, and Cottrans. (2010). Pathologic Basis of Disease. $\left(8^{\text {th }} \mathrm{ed}\right)$. Philadelphia: Saunders Elsevier.

Kathuria, N., Gupta, N., Manisha, R., Prasad, R., Nikita. (2011). Biologic 
Effects of Aloe Vera Gel. The Internet Journal of Microbiology, 9, 2.

Kurniawan, H. (2007). Efek Daun Kelor (Moringa Oleifera) dalam Mempercepat Penurunan Tanda Inflamasi Eritema pada Luka Bersih pada Marmut (Cavia Porcellus). The Indonesian Journal of Health Science, 1(1), 23-31.

Kozier, B. et al. (2008). Fundamental of Nursing: Concepts, Process and Practice. New Jersey. Pearson Education.

Marriner-Tomey \& Alligood. (2010). Nursing Theorists and Their Works. ( $7^{\text {th }}$ ed.) St.Louis: Mosby Elsevier, Inc. Mansjoer Ali, Kuspuji T., Rakhmi S., Wahyu Ika, Wiwik S.W. (2014). Kapita Selekta Kedokteran. (edisi 4). Jakarta: Media Aesculapius.

Mendonça, F.A.S., Passarini Junior, J.R., Esquisatto, M.A.M., Mendonça, J.S., Franchini, C.C., \& Santos, G.M.Td. (2009). Effects of the application of Aloe vera (L.) and microcurrent on the healing of wounds surgically induced in Wistar rats. Acta Cirúrgica Brasileira, 24(2), 150-55.

Nursalam. (2011). Manajemen Keperawatan: Aplikasi dalam Praktik Keperawatan Profesional Edisi 3. Jakarta: Salemba Medika.

Nugroho, W. (2008). Keperawatan Gerontik \& Geriatrik. (ed 3). Jakarta, EGC.

Oryan, A., Naeini, A.T., Nikahval B., Gorjian, E. (2010). Effect of aqueous extract of Aloe vera on experimental cutaneous wound healing in rat. Veterinarski arhiv, 80(4), 509-22.

Oyelami, O.A., Oneyami, A., Oyedeji, O.A., \& Adeyemi, L.A. (2009) Prelilminary Study of Effectiveness of Aloe Vera in Scabies Treatment. Journal Phytotheraphy Research, 23(10), 144882-4.

Pellizzoni, M., Ruzickova, G., Kalhotka, L., Lucini, L. (2012). Antimicrobial activity of different Aloe barbadensis
Mill. and Aloe arborescens Mill. leaf fractions. Journal of Medicinal Plants Research, 6(10), 1975-81.

Ramamoorthy, L., Kemp, M.C., Tizard, I.R., Ramamoorthy, L., Kemp, M.C., \& Tizard, I.R. ( 2011). Acemannan, beta-(1,4)-asetat Mannan, menginduksi produksi oksida nitrat dalam baris sel makrofag RAW 264,7. Retrieved from http://www.ncbi.nlm.nih.gov/pubmed/ 8863833 on April, 25 2012.

Setiabudi, A.W. (2008). Lidah Buaya. Retrieved from http//www.artikellidah-buaya/pages.htm on September $9^{\text {th }}, 2011$.

Sjamsuhidajat, R., \& Jong, W.D. (2011). Buku Ajar Ilmu Bedah Edisi ke 3. Jakarta: EGC.

Smeltzer, S., \& Bare, C. (2010). Brunner \& Suddarth's Textbook of Medical Surgical Nursing $12^{\text {th }}$ Edition. Philadelphia : Lippincott Williams \& Wilkins.

Sukmono, J. (2006). Pedoman Terapi Herbal. Jember: Sanggar Meditasi dan Tanaman Obat "Adem Ati".

Schwartz, S.I., Brunicardi, F.C., Anderson, D.K., Billiar, T.R., Dunn, D.L., Hunter, J.G., Mathews, J.B., \& Pollock, R.E. (2010). Schwartz's Principles of Surgery Ninth Edition. New York: McGraw Hill Professional. Tamher, S., \& Noorkasiani. (2009). Kesehatan Usia Lanjut dengan Pendekatan Asuhan Keperawatan. Jakarta.

Widagdo, T.D. (2010). Perbandingan Pemakaian Aloe Vera 25\%, 40\% dan Silver Sulfadiazine 1\% Topikal pada Penyembuhan Luka Bakar Derajad II. Retrieved from http://eprints.undip.ac.id/21436/

Wilksman, L.B., Solomonik, I., Spira, R., Tennenbaum, T. (2007). Novel Insights into Wound Healing Sequence of Events. Toxicologic Pathol, 35, 767-79.

Zakariya, M. (2008). Efektifitas 
Penggunaan Madu dibandingkan

Povidone Iodine $10 \%$ terhadap

Penyembuhan Luka Insisi pada

Marmut (Cavia Cobaya). Unpublished thesis by Faculty of Nursing, Airlangga University, Surabaya.

Cite This Article As: Toha, M., Sujarwadi, M., \& Zuhroidah, I. The Effect of Aloe Vera Extract and Discharge Planning to Accelerate Wound Healing of Older Adult Hernia Surgery Patients. Nurse and Health: Jurnal Keperawatan 2019; 8(2): 124133. 